\title{
Students' Ability in Writing Paragraph Components and Their Perceptions on Academic Essay as Reflected in the Students' Thesis
}

\author{
Trisna Yolanda ${ }^{1}$, Sitti Fatimah ${ }^{2}$, and Desvalini Anwar ${ }^{3}$ \\ ${ }^{1}$ Universitas Negeri Padang, Padang, Indonesia yolaanda241@gmail.com \\ ${ }^{2}$ Universitas Negeri Padang, Padang, Indonesia sitti.fatimahbing@gmail.com \\ ${ }^{3}$ Universitas Negeri Padang, Padang, Indonesia desvalinianwar@yahoo.co.id
}

\begin{abstract}
The ability to write academic essays is one of the learning outcomes that have to be achieved by the graduates of English Language Education Program (ELEP), in Universities in Indonesia. This ability will be helpful for helping the students to complete their undergraduate thesis. Preliminary observation shows challenges faced by the students in writing academic essay. Given that they have learnt all courses of academic writing, there is an assumption that they should have achieved an expected level of writing ability. However, some facts show the opposite. Thus, this study intends to obtain a picture of their ability by analyzing these recent graduates' academic essays, particularly the components of paragraphs (coherence, cohesion, unity) found in their undergraduate thesis. The current study also aims to find out the graduates' perceptions of academic essay. Using descriptive research, the data will be collected through document analysis and questionnaires.
\end{abstract}

Keywords: academic writing, paragraph components, perceptions

\section{INTRODUCTION}

Thesis writing is one of the academic essays required to be completed before students graduate from university. Therefore, writing skill needs to be taught to enable students to write their thesis well. In the English Department of Universitas Negeri Padang (UNP), there are five writing courses or five pre requested academic writing subjects that must be taken by the students. They need to take it before they came to thesis writing. Those are Paragraph Writing, Essay Writing, Academic Writing, Article Writing, and Paper/ Thesis Writing. Like some others university in Indonesia such as UPI and UNJA, English Department of those universities also offer writing subjects before students write their thesis. For example, in UPI, writing subjects are Writing For General Communication I, Writing For General Communication II, Writing in Professional Context, Writing For Academic Purpose I, Writing For Academic Purpose II, and Thesis Writing (English Department FBS UPI: 2019). Meanwhile, UNJA offers Paragraph Writing, Essay Writing, Academic Writing and Thesis Writing (FKIP UNJA: 2019). All of those courses are expected to enable students to have a better writing ability.

In order for a thesis to be easily understood by readers, it needs to have well written paragraphs containing unity, coherence and cohesion. These are called paragraph components. According to Boardman (2008), there are three paragraph components that must be included in producing a good paragraph and essay. Those components are unity, coherence and cohesion. To have a good unity, thesis must have supporting sentences that relate to topic sentence. Writing is said to be coherence when it established the correlation between one sentence with another sentence, or one paragraph with another paragraph. Writing is said to be cohesive if all supporting sentences connect to each other in their support of the topic sentence. Thus, a good paragraph consists of a group of related sentences that represents one main idea.

From a preliminary observation it was found that although students have accomplished all of the writing courses, it was found that their level of writing ability is still low. To ensure that this preliminary finding was correct, researcher did an informal interview with some students who are in the process of writing. They reported that writing thesis is difficult because there are many requirements in writing a thesis. They said that not all courses of writing are useful. They have difficulty in expressing main idea. Moreover, they also feel that academic writing is not interesting because it is different from the non academic one. Other students said that they do not like writing because it is boring.

Due to the students' confession that writing thesis is difficult, and the writing academic courses that have been taken are not useful, the researcher is also interested to investigate the students' perception of academic essay further. The result of students' perception is expected to find the causes of those problems appear. According to Wood (2009), perception is the active 
process of selecting, organizing, and interpreting people, object, events, situation and activities. The first thing to notice about this definition in this research is that perception is interpreting object actively not to passively.

The problems about students' ability in writing paragraph components that the researcher found in the paragraphs above are not found yet in the previous research. There are some researches of students' ability in writing, but they did not discuss yet about paragraph component. Most of the research focus on some essays, such as persuasive essay, exposition essay, argumentative essay, and so on. For instance, Misianto (2017) investigated students' ability in producing effective essay. The purpose was to analyze the rhetorical aspects, which are contents, organization of ideas, discourse, syntax, vocabulary, and mechanics. Although this reserach has already discussed about writing, but this research has not yet discussed about paragraph components. Thus, in the researcher's thesis here, this study focuses on paragraph components.

Furthermore, a research was from Sharif (2017). She expected to know students' perceptions of their reflective essay writing experience and teacher feedback comments. The content analysis showed that the students believed reflective writing played a small contribution to their language learning. Further investigation into the students' perspectives of their teachers' feedback comments suggests that even though the teachers' feedback was positive, the students also referred to the comments as inadequate and ineffective. Pedagogical implications and suggestions for future research are discussed. Otherwise, this research was still not discussing about the positive impact for learning outcome of the student. Therefore, this research would be discussed about students; perception toward their learning outcome.

In short, researcher is interested in investigating the ability of undergraduate students specifically in writing paragraph components. Moreover, the researcher also needs to analyze students' perception toward academic essay. The data will be collected from the thesis of English Language Education Program (ELEP) graduates of UNP in the three periods of ELEP graduation. The researcher focuses on the thesis of those graduates because they had completed writing courses of 2014 curriculum.

\section{METHOD}

This study is descriptive research. It just describes the phenomena without giving treatment. The population of this research is the graduates of English Language Teaching Education Program (ELEP) of UNP in academic year 2018/2019. The sample of this research is 23 softcopy theses of ELEP students. In taking samples, total sampling is used by researcher.

The researcher will analyze students' thesis background by using the scoring rubric of paragraph components. Then, the researcher will distribute the questionnaires through Google Form to graduates' email in order to know the students' perception of academic essay.
The graduates are English Language Education Program (ELEP) of UNP in the three periods of ELEP graduation.

The instruments will be in the form of document analysis and questionnaire. Then, technique of Data Collection, the researcher will get 23 theses of undergraduate student from the librarian of ELEP of UNP. The researcher will analyze all paragraphs in the background of the problem of the thesis by using the scoring rubric of paragraph components. Then, the researcher will distribute the questionnaires through Google Form to graduate students' email in order to know the students' perception of academic essay. In collecting the data, the researcher uses two instruments, namely documents analysis and questionnaire.

There are three stages of analyzing the data collected in this research: first, the wrong used of paragraph components are classified based on each undergraduate thesis. Second, the researcher presented the mean of undergraduate's thesis by using Johnson \& Christensen's (2008:473) formula. The researcher converge the percentage the students' ability in writing paragraph components by using Surakhmad's (1990) formula.

Researcher will classify the result score into ten categories of students' ability in writing paragraph components. The following grading system is adapted from conversion scale existed in English Language Education Program (ELEP) of Universitas Negeri Padang (UNP) which is stated in academic rules of UNP (2015). Then, the researcher finds out students' perception of academic essay in the questionnaire.

\section{RESULTS AND DISCUSSION}

This research was conducted in ELEP of UNP. The participants were undergraduate students graduated in the last three periods. The researcher collected the data from softcopy theses at library Language and Art faculty. Then, the researcher distributed the questionnaire in Google form to undergraduates' email. The data analyzed descriptively to answer the research questions "How is the ability of the undergraduates of ELEP of UNP in writing paragraph components?", "What is the perception of the Undergraduates of ELEP of UNP about academic essay?" and "Why undergraduates of ELEP of UNP have its perceptions toward their learning outcome?".

Table 1. The Result of Students' Ability in Writing Paragraph Components

\begin{tabular}{|c|c|c|}
\hline Total Score & $\begin{array}{c}\text { Number of } \\
\text { Students }\end{array}$ & Category \\
\hline 77,5 & 23 & Very Good \\
\hline
\end{tabular}

Based on Table the result of students' ability in writing paragraph components, the total score is 77,5 from 23 students. The category of the score is very good indicated that students have very good ability in understanding unity, coherence and cohesion. Thus, students' ability in writing paragraph components is very good. 
Table 2. The Result of Students' Perception on Academic Essay

\begin{tabular}{|c|c|c|c|c|c|c|c|c|c|c|c|c|c|c|c|c|}
\hline \multirow{2}{*}{ Category } & \multicolumn{10}{|c|}{ Statement } & \multicolumn{1}{c|}{$\begin{array}{c}\text { Tot } \\
\text { al }\end{array}$} \\
\cline { 2 - 17 } & $\mathbf{1}$ & $\mathbf{2}$ & $\mathbf{3}$ & $\mathbf{4}$ & $\mathbf{5}$ & $\mathbf{6}$ & $\mathbf{7}$ & $\mathbf{8}$ & $\mathbf{9}$ & $\mathbf{1 0}$ & $\mathbf{1 1}$ & $\mathbf{1 2}$ & $\mathbf{1 3}$ & $\mathbf{1 4}$ & $\mathbf{1 5}$ & \\
\hline SP & 5 & 5 & 6 & 8 & 10 & 8 & 4 & 4 & 1 & 7 & 7 & 7 & 7 & 2 & 6 & $\mathbf{8 7}$ \\
\hline P & 17 & 15 & 13 & 14 & 13 & 15 & 18 & 18 & 17 & 15 & 15 & 14 & 12 & 15 & 13 & $\mathbf{2 2 4}$ \\
\hline KP & 1 & 3 & 4 & 1 & & & & 1 & 5 & 1 & 1 & 2 & 4 & 6 & 4 & $\mathbf{3 3}$ \\
\hline
\end{tabular}

From Table of the result of students' perception on academic essay above, the researcher got the result that the total score of very understanding category is 87 . The next score, the understanding score is 224 . The last score, less understanding category score is 33 . In short, undergraduate students had understood about academic essay taught by the lecturers in ELEP of UNP.

The researcher explained the result of students' ability in writing paragraph component and their perception on academic essay based on the explanation from the expert above. First, students' ability in writing paragraph components such as unity, coherence and cohesion had been mostly included inside their writing. They have used the criteria in paragraph components of their writing. Second, students also delivered their perception on academic essay such as writing, paragraph writing, essay writing, academic writing, article writing and thesis writing. They also mentioned the reason of their perception why they choose very understand, understand and less understand. At least, most of the participants were having good ability in writing paragraph components and they have understood about academic essay.

The finding of this research is almost all of the undergraduate students got very good score in writing paragraph component from scoring rubric of paragraph component. They also understand the theory of all writing subject on academic essay which was learnt by them in the previous semester. It means that, students have a very good ability in writing thesis, because they have completed the good writing of paragraph component. Then, students also able to understand material of writing subject which was explained by the lecturer in the class. This has been provided by the participants in this research.

\section{CONCLUSIONS}

Based on the research questions stated in chapter 1, the purpose of this research is to analyze the ability of the undergraduates of ELEP of UNP in writing paragraph components, to know perception of the Undergraduates of ELEP of UNP about academic essay, and to know why undergraduates of ELEP of UNP have its perceptions toward their learning outcome. In collecting data, the researcher analyzed students' softcopy thesis anddistributed questionnaire to the students through their email. There are 23 students as participants of this research. Based on the result, students' ability in writing paragraph componentscan be categorized as very good with mean score 77,5 .
Furthermore, the researcher checks students' perception on academic essay by using questionnaire. The indicators are adopted from syllabus of all courses of writing such as writing, paragraph writing, essay writing, academic writing, article writing and thesis writing. Based on the result of questionnaire, students' perception on academic essay is they understand the materials and theories of writing. Most of them said that because they learnt writing step by step and the lecturer who was taught writing subjects help them to write a good writing. Thus, their very good score of paragraph components and their understand perception on academic essay are relate one another. It produces a good writing which having the good learning outcome of undergraduate students of ELEP of UNP.

\section{REFERENCES}

[1] Anita, Rini. (2012). Students' Ability in Writing an Introductory Paragraph of Argumentative Essay. Ta'dib, Vol. 15, No. 2.

[2] Aruan, Rumiri \& Sepri, Eva. Y. (2010). The Ability of the Fourth Semester English Department Students of FKIP UR in Writing a Persuasive Essay. English Study Program of FKIP Riau University.

[3] Bacha, N.N. (2003). Developing Learners' Academic Writing Skills in Higher Education: A study for educational reform. Language and Education.

[4] Bailey, M. Hellen. (2014). Academic Journal, Clause Relations and Macro Pattern: Cohesion, Coherence and the Writing of Advanced ESOL Students. Retrieved on January 4, 2014.

[5] Boardman, A. Cynthia \& Frydenberg, Jia. (2008). Writing to Communicate Paragraph and Essays. New York: Pearson Education.

[6] Creswell, John. W. (2012). Educational Research: Planning, Conducting, and Evaluating Quantitative and Qualitative Research the Fourth Edition. Boston: Pearson Press.

[7] Cohen, Louis, Lawrence Manion \& Keith, Marrison. 2007. Research Method in Education Sixth Edition. Canada: Routledge

[8] English Department FBS UNP. (2019). Vision and Mission.

http://english.fbs.unp.ac.id/index.php/samplepage/vision-mission/. March, 2, 2019.

[9] English Department FBS UNP. (2019). Program Learning

Outcome. http://english.fbs.unp.ac.id/index.php/studyprograms/english-language-teaching-studyprogram/program-learning-outcome/. March, 2, 2019.

[10] Greene, B.B. (2001). Testing Reading Comprehension of Theoritical discourse with Cloze. Journal of Research in Reading. 
[11] Halliday, M. A. K \& Hasan, Ruqaiya. (1976). Cohesion in English. London and New York: Longman.

[12] Harry, Gunadi \& Suharyadi. (2018). The Profile of EFL Learners as measured by An English Proficiency Test. JEELS. Universitas Negeri Malang, Indonesia.

[13] Hyland, Ken. (2003). Second Language Writing. Cambridge University.

[14] Harmer, Jeremy. (2004). Just: Intermediate, Reading and Writing. Langenscheidt.

[15] Information Services Department (2006). Hong Kong Year Book. Hong Kong, Hong Kong SAR: Information Services Department.

[16] Johnson, B., \& Christensen, L. (2008). Educational research. California: Sage Publications, Inc.

[17] Langan, John. (2006). Reading and Study Skills. McGraw-Holl College. Pennsylvania State University.

[18]Li, G., Chen, W. \& Duanmu, J-L. (2010). Determinants of International Students' Academic Performance: A Comparison between Chinese and other International Students. Journal of Studies in International Education.

[19] Mahmud, Jafar. (2004). Introduction to Psychology. New Delhi: Nisha Enterprises.

[20] Mayers, Alan. (2014). Longman Academic Writing Series: Essays to Research Papers. United States of Amerika: Pearson Education.

[21] Misianto. (2014). Improving Students' Ability in Writing an Essay through Peer-Assessment Strategy at The Fifth Semester in Cipta Wacana Christian University of Malang. Jurnal Ilmiah dan Sastra: Vol.1, No. 1.

[22] Oshima, A \& Hogue, A. (2006). Writing Academic English. New York: Pearson Education.

[23]Rao, Valli. (2007). A Visual Guide to Essay Writing: How to Develop and Communicatie Academic Argument. Valli Rao.

[24] Rintaningrum, Ratna., Carol. A. \& John. P. Keeves. (2017). The Influence of Student Background Characteristics on Proficiency in English as a Foreign Language: Indonesian context: Jurnal Sosial Humaniora.

[25] Robinson, Howard. (1994). Perception. New York: Routledge.

[26] Savage, A \& Shafiei, M. (2007). Effective Academic Writing 1: The Paragraph. Oxford University Press.

[27] Silfia, Efa. (2014). An Analysis of the Students' Ability in Writing Exposition Essay by Contrast Development at $11^{\text {th }}$ Year Students of SMAN 3 Sungai Penuh.

[28] Saukah, Ali. (2000). The English Proficiency of the Academics of the Teacher Training and
Education Institutions. English Language Education, State University of Malang.

[29] Scott, David. (2003). Curriculum Studies: Curriculum Knowledge. Taylor and Francis

[30] Sharif, Mohd Asiah \& Zainuddin, Siti Zaidah. (2016). Students' Perceptions of their Reflective Essay Writing Experience and Teacher Feedback Comments. University of Malaya.

[31] Surakhmad. W. (1990). Pengantar penelitian ilmiah. Bandung: Tarsito

[32] Tozoglu, Dogan \& Musavver D. Tozoglu. (2004). The Students' Perceptions: Essay Versus MultipleChoice Type Exams. Turki: Journal of Baltic Science Education.

[33] West, Richard \& Turne, Lynn. H. (2009). Understanding Interpersonal Communication. Boston: Wodsworth Cengange Learning.

[34] Wood, Julia. (2009). Communication In Our Lives. Boston: Wodsworth Cengange Learning.

[35] Yakhontova, T.V. (2003). English Acaddemic Writing: for Students and Researchers. USA: New York. Longman.

[36]Zemach, Dorothy E \& Lisa, A. Rumisek. (2005). Academic Writing: From Paragraph to Essay. Oxford: Machmillan Publisher Limited.

[37]Zemach, Dorothy E \& Lisa, A. Rumisek. (2003). College Writing: From Paragraph to Essay. Oxford: Machmillan Publisher Limited. 